\title{
Monthly Rainfall Erosivity: Conversion Factors for Different Time Resolutions and Regional Assessments
}

Panos Panagos ${ }^{1, *}$, Pasquale Borrelli ${ }^{1}$, Jonathan Spinoni ${ }^{1}$, Cristiano Ballabio ${ }^{1}$, Katrin Meusburger ${ }^{2}$, Santiago Beguería ${ }^{3}$, Andreas Klik ${ }^{4}$, Silas Michaelides ${ }^{5}$, Sašo Petan ${ }^{6}$, Michaela Hrabalíková ${ }^{7}$, Preben Olsen ${ }^{8}$, Juha Aalto ${ }^{9}$, Mónika Lakatos ${ }^{10}$, Anna Rymszewicz ${ }^{11}$, Alexandru Dumitrescu ${ }^{12}$, Melita Perčec Tadić ${ }^{13}$, Nazzareno Diodato ${ }^{14}$, Julia Kostalova ${ }^{15}$, Svetla Rousseva $^{16}$, Kazimierz Banasik ${ }^{17}$ and Christine Alewell ${ }^{2}$

1 European Commission, Joint Research Centre, Institute for Environment and Sustainability, Via E. Fermi 2749, I-21027 Ispra (VA), Italy; pasquale.borrelli@jrc.ec.europa.eu (P.B.); jonathan.spinoni@ext.jrc.ec.europa.eu (J.S.); cristiano.ballabio@jrc.ec.europa.eu (C.B.)

2 Environmental Geosciences, University of Basel, Bernoullistrasse 30, CH-4056 Basel, Switzerland; katrin.meusburger@unibas.ch (K.M.); christine.alewell@unibas.ch (C.A.)

3 Estación Experimental de Aula Dei, Consejo Superior de Investigaciones Científicas (EEAD-CSIC), 50009, Zaragoza, Spain; santiago.begueria@csic.es

4 Institute of Hydraulics and Rural Water Management, University of Natural Resources and Life Sciences, Muthgasse 18, AT-1190 Vienna, Austria; andreas.klik@boku.ac.at

5 The Cyprus Institute, 20 Konstantinou Kavafi Street, CY-2121 Nicosia, Cyprus; silas.michaelides@gmail.com

6 Slovenian Environment Agency, Hydrology and State of Environment Office, Cesta 4. julija 67, SI-8270 Krško, Slovenia; saso.petan@gmail.com

7 Faculty of Environmental Sciences, Czech University of Life Sciences, Kamýcká 129, 16521 Prague, Czech Republic; hrabalikova@gmail.com

8 Department of Agroecology, Aarhus University, Blichers Alle 20, 8830 Tjele, Denmark; Preben.Olsen@agrsci.dk

9 Finish Meteorological Institute, P.O Box 503, FI-00101 Helsinki, Finland; juha.aalto@fmi.fi

10 Hungarian Meteorological Service, Kitaibel Pál street 1, HU-1024, Budapest, Hungary; lakatos.m@met.hu

11 UCD Dooge Centre for Water Resources Research, University College Dublin, Belfield, Dublin 4, Ireland; anna.rymszewicz@ucdconnect.ie

12 Department of Climatology, National Meteorological Administration, Bucuresti-Ploiesti 97, RO-013686, Bucharest, Romania; alexandru.dumitrescu@gmail.com

13 Meteorological and Hydrological Service, Grič 3, HR-10000, Zagreb, Croatia; melita.percec.tadic@cirus.dhz.hr

14 Met European Research Observatory, 82100 Benevento, Italy; scodalabdiodato@gmail.com

15 Slovak Hydrometeorological Institute, Climatological service Jeséniova 17, SK-83315 Bratislava, Slovakia; Julia.Kostalova@shmu.sk

16 Institute of Soil Science, Agrotechnologies and Plant Protection N. Poushkarov, Shosse Bankya Str. No7, BG-1336, Sofia, Bulgaria; svetlarousseva@gmail.com

17 Warsaw University of Life Sciences, ul. Nowoursynowska 166, Warsaw PL-02-787, Poland; kazimierz_banasik@sggw.pl

* Correspondence: panos.panagos@jrc.ec.europa.eu; Tel.: +39-0332-785574

Academic Editor: Ataur Rahman

Received: 21 January 2016; Accepted: 22 March 2016; Published: 26 March 2016

Abstract: As a follow up and an advancement of the recently published Rainfall Erosivity Database at European Scale (REDES) and the respective mean annual R-factor map, the monthly aspect of rainfall erosivity has been added to REDES. Rainfall erosivity is crucial to be considered at a monthly resolution, for the optimization of land management (seasonal variation of vegetation cover and agricultural support practices) as well as natural hazard protection (landslides and flood prediction). We expanded REDES by 140 rainfall stations, thus covering areas where monthly R-factor values were missing (Slovakia, Poland) or former data density was not satisfactory (Austria, France, and 
Spain). The different time resolutions (from 5 to $60 \mathrm{~min}$ ) of high temporal data require a conversion of monthly R-factor based on a pool of stations with available data at all time resolutions. Because the conversion factors show smaller monthly variability in winter (January: 1.54) than in summer (August: 2.13), applying conversion factors on a monthly basis is suggested. The estimated monthly conversion factors allow transferring the R-factor to the desired time resolution at a European scale. The June to September period contributes to $53 \%$ of the annual rainfall erosivity in Europe, with different spatial and temporal patterns depending on the region. The study also investigated the heterogeneous seasonal patterns in different regions of Europe: on average, the Northern and Central European countries exhibit the largest R-factor values in summer, while the Southern European countries do so from October to January. In almost all countries (excluding Ireland, United Kingdom and North France), the seasonal variability of rainfall erosivity is high. Very few areas (mainly located in Spain and France) show the largest from February to April. The average monthly erosivity density is very large in August (1.67) and July (1.63), while very small in January and February (0.37). This study addresses the need to develop monthly calibration factors for seasonal estimation of rainfall erosivity and presents the spatial patterns of monthly rainfall erosivity in European Union and Switzerland. Moreover, the study presents the regions and seasons under threat of rainfall erosivity.

Keywords: REDES; R-factor; seasonal rainfall intensity; modeling; soil erosion; monthly erosion rate

\section{Introduction}

Soil erosion by water is usually takes place in non-flat areas, when rainfall (and consequently surface runoff) falls on soils poorly covered with vegetation and without protective measures [1]. In Europe, soil loss by water erosion is mostly modeled using the Revised Universal Soil Loss Equation (RUSLE) [2]. RUSLE takes into consideration 6 factors: rainfall erosivity, soil erodibility, slope steepness and length, cover-management, and support practices. These factors are characterized by large spatial variability across the European Union, resulting in very heterogeneous spatial patterns of soil loss. Among the six factors, rainfall erosivity and cover-management have a high temporal variability during the different months of the year. Thus, data on rainfall erosivity in combination with vegetation cover and support management practices can facilitate useful assessments of soil erosion at local/regional scales to large scales. Further, the intra-annual variation in rainfall erosivity affects agriculture, forestry, hydrology, water management, and ecosystem services. Consequently, neglecting the seasonal variability of rainfall erosivity and as a result, the intra-annual soil loss variability, may lead to improper decision making [3].

Rainfall erosivity, measured with the R-factor in RUSLE, accounts for the erosive power of rainfall and the subsequent runoff [4]. Rainfall erosivity results in detachments of soil particles and their transport by runoff. The R-factor is calculated from a series of single storm events by multiplying the total storm kinetic energy (calculated by an empirical relationship) with the measured maximum 30-min rainfall intensity [5]. The R-factor of the erosive events is summed over long time periods (more than 22 years recommended) and then annual R-factor values can be calculated [4].

By definition, the R-factor is calculated using breakpoint rainfall information taken from continuous recording rain gauge charts $[5,6]$. However, it is not always possible to have recordings available at very high temporal resolution (1-min, 5-min) due to the setup of rainfall stations. The availability of high temporal resolution data (30-min, 60-min) has been increasing during the last decades due to the large number of rainfall stations and the technological advancements. During the last decade, data from high temporal resolution rainfall stations have been increasingly available in Belgium, France, Germany, Luxembourg, Estonia, Latvia, Finland, Romania, Italy and Portugal [7]. The accuracy of the R-factor depends greatly on the time interval at which precipitation is recorded. 
Depending on the resolution of rainfall data, Renard et al. [4] developed regression equations that 'transfer' the R-factor values from coarse resolution (e.g., 60-min) to higher resolution(s) (e.g., 15-min).

In this study, we present functions for calibrating rainfall erosivity at different resolutions and on a monthly basis. Based on these calibration functions, a station-based monthly erosivity dataset at a common time resolution of 30-min has been produced. As the second part of this study, the calibrated station-based monthly R-factor values are used for producing the first assessment of seasonal rainfall erosivity at the European scale.

\section{Materials: Rainfall Erosivity Database at European Scale (REDES) and 2015 Updates}

The first version of the Rainfall Erosivity Database at the European Scale (REDES) included 1541 rainfall stations within the European Union (EU) and Switzerland [7]. The rainfall erosivity has been calculated in REDES by using high temporal resolution data (5-min, 10-min, 15-min, 30-min and 60-min) for periods ranging from 7 to 56 years (average length 17.1 years) and applying the equations proposed by Brown and Foster [8]. The rainfall erosivity map of Europe and other derived datasets (erosivity density, standard error) are available for download from the European Soil Data Centre (ESDAC). Due to space constraints, here we limit the description of the REDES database development and characteristics; for further details on REDES, the input rainfall data, the data availability and the updates, please see Panagos et al. [7] and Panagos et al. [9].

In 2015, REDES was updated by adding 134 new rainfall stations (8.5\% increase). In Austria, 53 stations were added mainly covering the southern regions of the country (Tyrol and Carinthia), where the R-factor has been measured to be larger than $4000 \mathrm{MJ} \mathrm{mm} \cdot \mathrm{ha}^{-1} \cdot \mathrm{h}^{-1} \cdot$ year $^{-1}$ (Nassfeld station) [9]. In Slovakia, 22 stations were added to REDES, as the existing 81 stations had only annual R-factor values from the literature. Finally, 21 stations (well distributed in the country) were added in France, 4 stations in Poland and 33 stations in 4 Spanish catchments (Galicia, Júcar, Ebro and Hidrosur) (Figure 1).

The main objective of the REDES update (during 2015) was to cover areas with data gaps (Poland, Spain, South Austria, and France) and to insert new data where seasonal R-factor values were not available (Slovakia). The updated REDES included 1675 rainfall stations with high-resolution rainfall data. Monthly R-factor values have been calculated for the 1568 stations out of 1675 as the rest of the stations (107) have only annual R-factor values retrieved from the literature. 


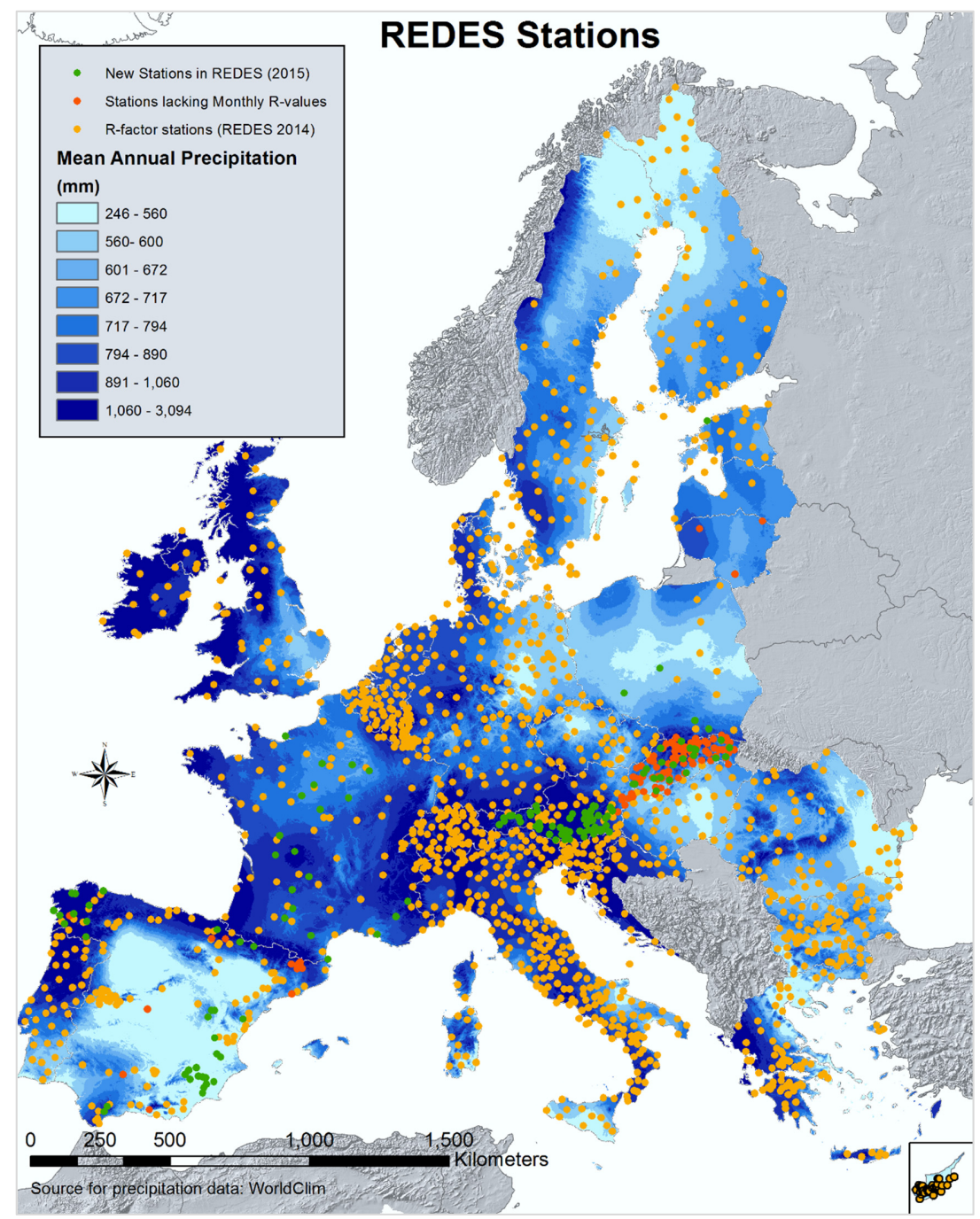

Figure 1. Rainfall stations included in the Rainfall Erosivity Database on the European Scale (REDES) (In green color, the new stations added to REDES (2015); in red color, the stations lacking monthly R-factor values, in yellow color, REDES (2014)).

\section{Methods}

The data collection of the high-temporal-resolution rainfall records has been explained in Panagos et al. [7]. After the recent REDES update with the new 134 records, the methods include three further steps: (a) calculation of monthly erosivity values per station; (b) normalization of R-factor values calculated using rainfall data with different time steps ( 5 to $60 \mathrm{~min}$ ); and (c) spatial analysis of intra-annual (monthly) rainfall erosivity and erosivity density.

\subsection{Monthly R-factor Calculation}

Despite the high importance of seasonal rainfall erosivity variation, few studies have analyzed its inter-annual and spatial variability [10-13]. In the calculation of the original REDES dataset and in the present paper, we have applied the rainfall energy equation proposed by Brown and Foster [8] for the R-factor calculation and followed the criteria for the identification of erosive events [4]. This methodology is briefly described as follows. 
The R-factor is the product of the kinetic energy of a rainfall event $(E)$ and its maximum 30-min intensity $\left(I_{30}\right)$ :

$$
R=\frac{1}{n} \sum_{j=1}^{n} \sum_{k=1}^{m_{j}}\left(E I_{30}\right)_{k}
$$

where $R$ is the average monthly rainfall erosivity (MJ. mm $\left.\cdot \mathrm{ha}^{-1} \cdot \mathrm{h}^{-1} \cdot \mathrm{month}^{-1}\right), n$ is the number of years recorded, $m_{j}$ is the number of erosive events during a given month $j$, and $E I_{30}$ is the rainfall erosivity index of a single event $k$.

The erosivity of a single event $E I_{30}\left(\mathrm{MJ} \mathrm{mm} \mathrm{ha}{ }^{-1} \mathrm{~h}^{-1}\right)$ is defined as:

$$
E I_{30}=\left(\sum_{r=1}^{m} e_{r} v_{e}\right) I_{30}
$$

where $e_{r}$ is the rainfall kinetic energy $\left(\mathrm{MJ} \cdot \mathrm{ha}^{-1} \cdot \mathrm{mm}^{-1}\right.$ ) and $v_{r}$ is the rainfall volume (mm) during the $\mathrm{r}$-th period of a storm that is divided into m-parts.

The rainfall kinetic energy $\left(e_{r}\right)$ per rainfall depth $(\mathrm{mm})$ and per unit area (ha) for each time interval is calculated as follows [8]:

$$
e_{r}=0.29\left[1-0.72 \exp \left(-0.05 i_{r}\right)\right]
$$

where $i_{r}$ is the rainfall intensity during the time interval $\left(\mathrm{mm} \mathrm{h}^{-1}\right)$.

The sums of $E I_{30}$ and the average R-factor have been calculated on a monthly basis. To compute the R-factor, the erosive rainfall events $\left(m_{j}\right)$ for each station have been selected based on thresholds set by Renard et al. [4] followed by Panagos et al. [7]. The Rainfall Intensity Summarisation Tool (RIST) software [14] has been used to calculate the R-factor. Moreover, this tool also derives the monthly R-factor values, allowing us to build the monthly "dimension" in REDES. Our database with monthly average erosivity values is made up of 12 monthly values per 1568 stations (i.e., 18,816 records).

\subsection{Calibration of Monthly R-factors Calculated from Different Temporal Resolution Rainfall Data}

The objective of this calibration is to account for the impact of differences in the time resolution of rainfall records on rainfall erosivity, and furthermore to develop calibration functions making the REDES homogeneous at a common time resolution of 30-min. The issue of different time resolutions for R-factor estimation has been faced in the past as well. Weiss [15] estimated the conversion factor between $E I_{30}$ and $E I_{15}$ at 1.0667. In the United States, Renard et al. [4] developed a range of coefficients varying from 1.08 to 3.16 in order to "transfer" R-factor values calculated on an hourly basis to $30 \mathrm{~min}$ $\mathrm{R}$-factor values based on measurements from 713 stations. Yin et al. [16] calculated the conversion factors between different resolutions based on measurements of 5 stations in China. Agnese et al. [17] also estimated the R-factor at 3 different resolutions (5-min, 15-min, and 60-min) for 7 stations in Sicily (Italy). In the European Union, Panagos et al. [7] developed calibration functions based on R-factor estimations at 5 different resolutions (60-min, 30-min, 15-min, 10-min, and 5-min). According to the REDES statistics, $23.4 \%$ of the European stations have rainfall data at very high resolution ( $<15 \mathrm{~min}$ ). Taking into account this fact, the calibration functions are necessary to provide consistent estimations of the R-factor for a wide area such as Europe.

The REDES database includes stations that have different recording intervals: $60 \mathrm{~min}, 30 \mathrm{~min}$, $15 \mathrm{~min}, 10 \mathrm{~min}$ and $5 \mathrm{~min}$. A calibration procedure has been followed for transforming the R-factor values to a common time resolution of $30 \mathrm{~min}$. In this way, REDES becomes homogenous in terms of time resolution, and allows assessments of annual and monthly erosivity. Using a geographically representative pool of rainfall stations with different time resolutions, four calibration functions have been produced in order to 'transform' the R-factor values to 30-min resolution [7]. The calibration process included the following steps: 
- $\quad$ The R-factor was calculated at the highest available resolution (i.e., <30 min) for a number of stations (86 stations well distributed across Europe).

- $\quad$ Data have been aggregated to coarser resolution(s) and the R-factor was calculated at the coarser resolution for the same stations.

- A calibration function, derived from regression analysis, has been developed based on the R-factor results at the highest possible resolution and the coarser resolution(s).

The four calibration functions were derived from the annual R-factor values and are applicable for the normalization of annual erosivity. Since the R-factor has different monthly patterns-due to the different monthly precipitation regimes-the annual regression functions would be inappropriate for the calibration of monthly R-factor values. Thus, we decided to develop calibration functions per month, following the same procedure as in the calibration of annual R-factor values. Those calibration functions have been developed for each month and for all applied resolutions (5-min, 10-min, 15-min and $60-\mathrm{min}$ ). The pool of rainfall stations involved in this calibration exercise was selected because of their data availability at multiple temporal resolutions. Moreover, the pool well represents the study area (stations from 14 countries: Belgium, Czech Republic, Switzerland, Cyprus, Germany, Estonia, Spain, France, Croatia, Hungary, Italy, Luxembourg, Romania, Slovenia) and their data recordings cover the last 10-25 years.

In an ideal situation where rainfall data at very high resolution $(<15 \mathrm{~min})$ could be available for all European countries, the calibration functions could be estimated even per climatic zone in Europe. For example, you cannot develop calibration functions per climatic region for the 15-min resolution when rainfall data at this scale are available only for Spain and Belgium. The same applies for the calibration functions for the 10-min resolution as the rainfall data at this scale are available for 4 countries (Croatia, Hungary, Romania and Switzerland) (Table 1 in [7]). Due to exceptional requests to the Environmental and Climatic services in Czech Republic, Cyprus, Germany, Estonia and Luxembourg, the pool of stations with 10-min rainfall data included 9 countries well-distributed in Europe (Table 2 in [7]) and allowed us to develop calibration functions at the European scale. Considering the potential of the REDES database, as further improvements, we plan exploring the possibility to obtain conversion factors that vary from region to region, and even enlarge the sample data for regression analyses.

The REDES database includes stations whose data spans from 7 to 56 years, thus covering a temporal period of many decades, from the 1960's to the last decade. This period is well known to have been undergoing climate change, in particular the last three decades, which experienced a global warming trend and a more pronounced rate of rainfall extreme events that involved Europe as well $[18,19]$. Though the preliminary tests we performed, it was proved that the monthly calibration functions show slight differences if computed using stations with different periods of data. Thus, we decided to use input data from the latest 25 years, in order to avoid possible biases introduced by different temporal rainfall regimes. Moreover, choosing the latest years, it follows that the calibration functions are effectively representing the physical characteristics of the last decade; consequently, the applications of such factors can be extended to newly collected data. We also highlight that, based on our tests, monthly conversion factors are more subject to spatial rainfall patterns than temporal issues, provided that the input data used to calculate them range over a sufficiently long period (i.e., 20 years) [9].

\section{Results and Discussion}

\subsection{Regression Curve for Annual R-factor Value}

In addition to the 4 calibration functions proposed by Panagos et al. [7], stations with data at very high resolution (1-min) from the Czech Republic and Slovakia have been used. The R-factor calculated with 30-min data is 0.7496 times lower than the R-factor calculated at 1-min data and 1.5597 times higher than the R-factor calculated at 60-min data. The term 'calibration factor' is used below to represent this conversion between the R-factor at different resolutions and the R-factor at 30-min. 
Based on the six calibration factors at the corresponding time resolutions $(1,5,10,15,30$ and 60 -min), a regression function has been developed (Figure 2). The limited number of calibration factors is a source of uncertainty and the regression function should be handled with care and used only for the entire study area. The regression function allows estimating calibration factors at every temporal resolution between 1 and $60 \mathrm{~min}$, though it is uncommon to use rainfall data at time resolutions different from those shown in Figure 2.

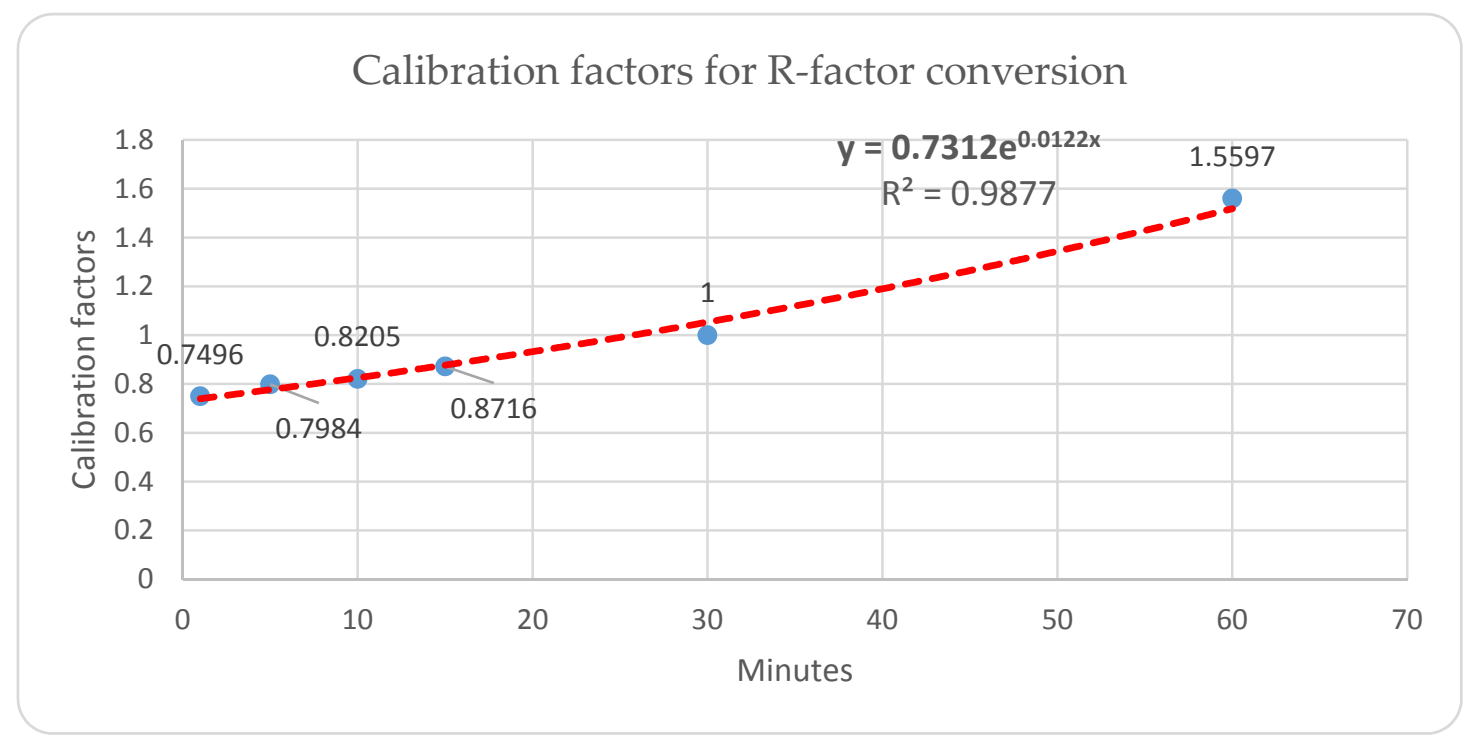

Figure 2. Suggested regression curve for R-factor values at different time resolutions in Europe with the 30-min resolution data set as a reference value.

The results of the annual calibration showed that the calibration factors in Europe are closer to the smallest values obtained by Renard et al. [4]. The estimated calibration factors match well with the findings in Sicily [17], Calabria [20], United States [6,21], and they are 10\%-20\% larger than the ones estimated in China [16]. However, not only the precipitation regimes of China (e.g., [22,23]) are remarkably different from the corresponding European ones [24], but also the general physical, climatic, and hydrological features are dissimilar compared to European ones ([25,26]); thus, similar calibration factors are not to be expected.

\subsection{Monthly Calibration Factors for Different Temporal Resolution}

The annual calibration factor for the R-factor estimation using the 60-min data has been estimated to be 1.5597, ranging from 1.2974 (January) to 1.6995 (August). The smallest calibration factors are estimated in winter, while the largest ones are found in summer (Figure 3). Compared with using one single calibration factor for the whole year, the option to apply monthly calibration factors is recommended, as there is $25 \%$ variability in the monthly conversion factors.

The annual calibration factor for estimating an annual R-factor by using 10-min data has been estimated at 0.8205 , ranging from 0.7986 (July) to 0.8951 (January). The smoothest calibration factors (closer to 1) are found in winter. The monthly conversion factors allow us to reallocate the R-factor at the desired resolution even if the data are available at coarser resolution. For example, the August R-factors at 60 -min can be converted to 5-min by multiplying them by a factor 2.13, while the January ones are multiplied by a factor 1.54 (Figure 3). In addition, the calibration factors between very high-resolution (e.g., between 15-min and 5-min) vary between 1.05-1.12 for the different months. 


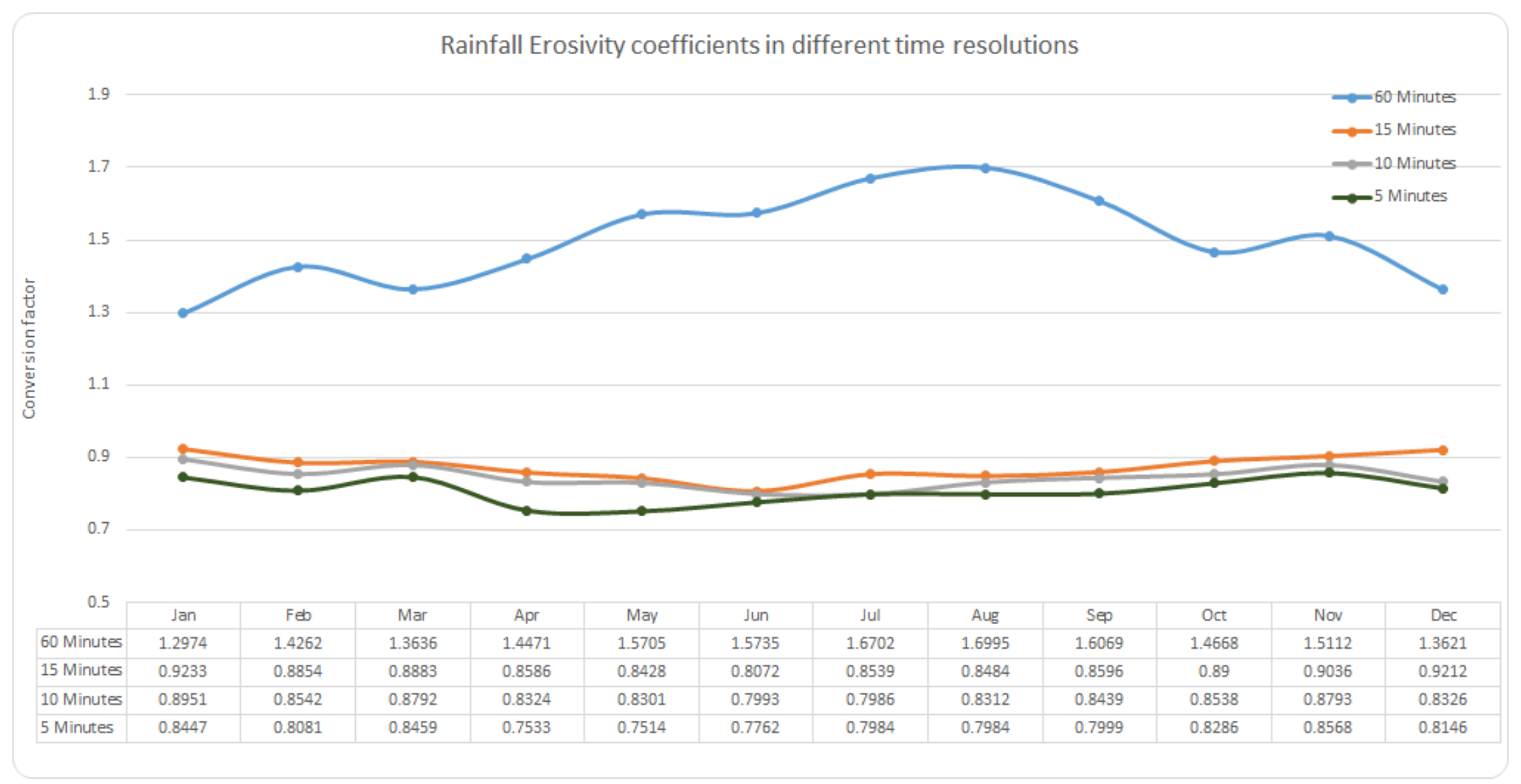

Figure 3. Monthly rainfall erosivity calibration factors for different resolutions (5-min, 10-min, 15-min, 60-min) compared to the R-factor base resolution of 30-min. 
The good performance in terms of coefficient of determination $\left(\mathrm{R}^{2}\right)$ in both the annual calibration functions and in the monthly ones permitted us to develop general pan-European calibration functions (Figure 3) that can be used in regional assessments in the case that better data than REDES are not available.

As the number of stations with available data at different time resolutions was 86 across Europe, it was impossible to develop regression functions per climatic region and per time resolution. Even if each climatic zone may have slightly different calibration functions, the objective of this study was to focus at the European scale (Figure 3).

\subsection{Seasonal and Monthly Rainfall Erosivity}

The annual R-factor map of Europe [7] gives a spatial overview of the potential of rain to cause erosion and allows identification of hot-spots where intervention may be needed. However, the control measures (agricultural, crop management and support practices) can be more efficient if the temporal distribution of rainfall erosivity is known. The temporal analysis of the two dynamic erosion factors (rainfall erosivity and cover-management) is important to take control measures against erosion [27]. Most of the RUSLE applications worldwide did not take into account the temporal variability of these two factors despite those intra-annual dynamics being documented in the RUSLE manual [4]. The monthly R-factor in combination with a future pan-European study on modeling seasonal cover-management represents a relevant step ahead in the framework of soil loss monitoring at the European scale [28]. This can be achieved by modifying the classical RUSLE approach to estimate average annual soil loss and propose the seasonal erosivity [29] in combination with intra-annual land cover variability and closer monitoring of management practices. Increasing availability of remote sensing data on land cover and vegetation (e.g., COPERNICUS programme; [30]) can contribute to a seasonal estimation of a cover-management factor.

The mean R-factor of the updated REDES (1675 stations) is $906 \mathrm{MJ} \cdot \mathrm{mm} \mathrm{ha}^{-1} \mathrm{~h}^{-1}$ year $^{-1}$; close to the one estimated in 2014. The monthly R-factor was calculated for 1,568 stations only due to the lack of monthly R-factor values at 107 stations whose annual $R$-factor values have been retrieved from the literature. The stations excluded are mainly located in Slovakia (81 stations), Spain and Lithuania and have small rainfall erosivity values. Those excluded small values have a small effect in aggregating slightly larger mean monthly R-factors values.

July and August are the months in which the highest number of intense erosive events occur in Europe (Figure 4). More than $40 \%$ of total rainfall erosivity in the European Union and Switzerland takes place in the summer period and more than $53 \%$ is noticed during the period June-September. According to the monthly distribution of rainfall erosivity in Europe, the mean R-factor does not show significant variations during the first four months (January to April) of the year, followed by a remarkable linear increase until July/ August (Figure 4). Finally, a smoother decrease, compared to the summer increase, is noticed during autumn and continues until February.

Within Europe, geographic differences exist in the seasonal patterns of rainfall erosivity. The stations with the absolute largest R-factor value in a single month (for instance July, August, September or October) are located mostly in Italy and Slovenia. For each REDES station, the season (spring, summer, autumn, winter) with the largest R-factor has been selected (Figure 5). For $94 \%$ of the REDES stations, the most erosive period is either summer (68\%) or autumn ( $26 \%)$. For only 22 REDES stations, mainly located in South Spain and France, the most erosive period is spring (Figure 5).

During summer, the R-factor exhibits its largest seasonal values for stations located in Northern European countries, i.e., the Baltic States, Scandinavia, Central and Eastern Europe, the Alpine region and the Apennines, as it can be seen from the distribution of the seasons with the largest R-factor values (Figure 5). This zone covers the largest part of Europe. A second zone, where autumn is the most erosive period, includes parts of the Mediterranean basin (Western Greece, coastal Italy, south France, Portugal and major part of Spain, Croatia and coastal Slovenia). As the Mediterrean basin has a complex morphology (e.g., sharp orographic features), there areas where stations with the highest 
R-factor values in all seasons are close to each other. A third zone, where winter is the most erosive period is limited to Cyprus, Crete, part of Greece and Galicia. Finally, a mixed situation where summer and autumn are dominant erosive periods is noticed in United Kingdom, Ireland and part of North France. On average, more than 55\% of the total annual R-factor [E1] takes place in only one season.

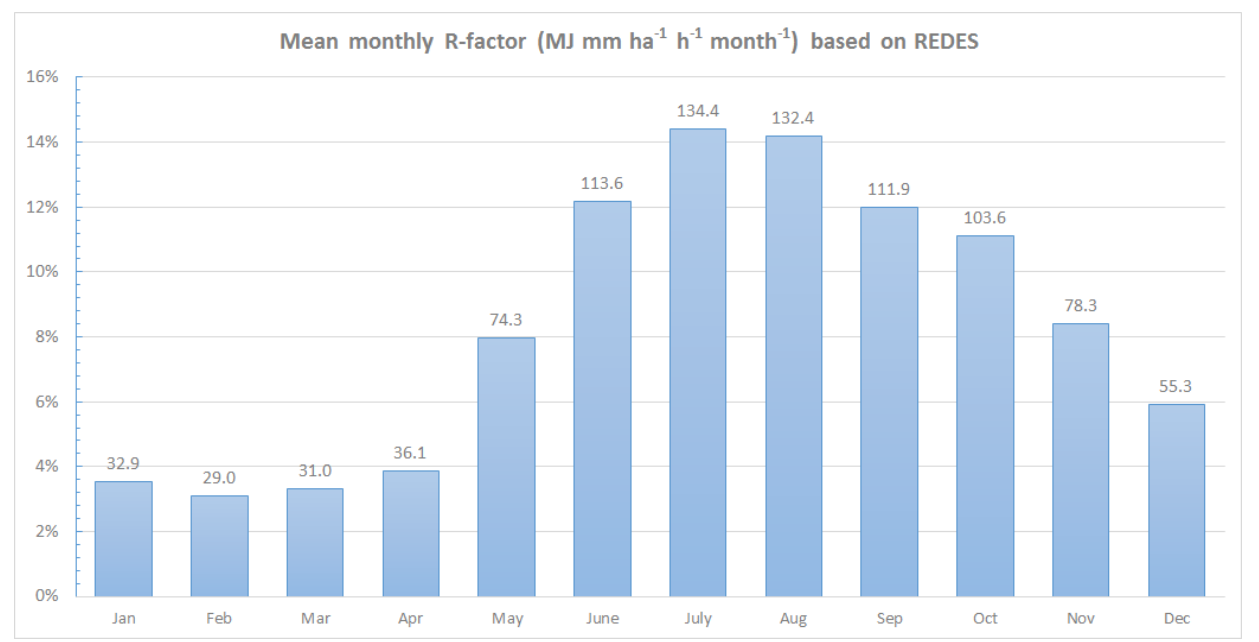

Figure 4. Monthly contribution (\%) to the annual R-factor and mean monthly R-factor (top of columns in $\mathrm{MJ} \mathrm{mm} \mathrm{ha}{ }^{-1} \mathrm{~h}^{-1}$ month $^{-1}$ ) of the REDES stations.

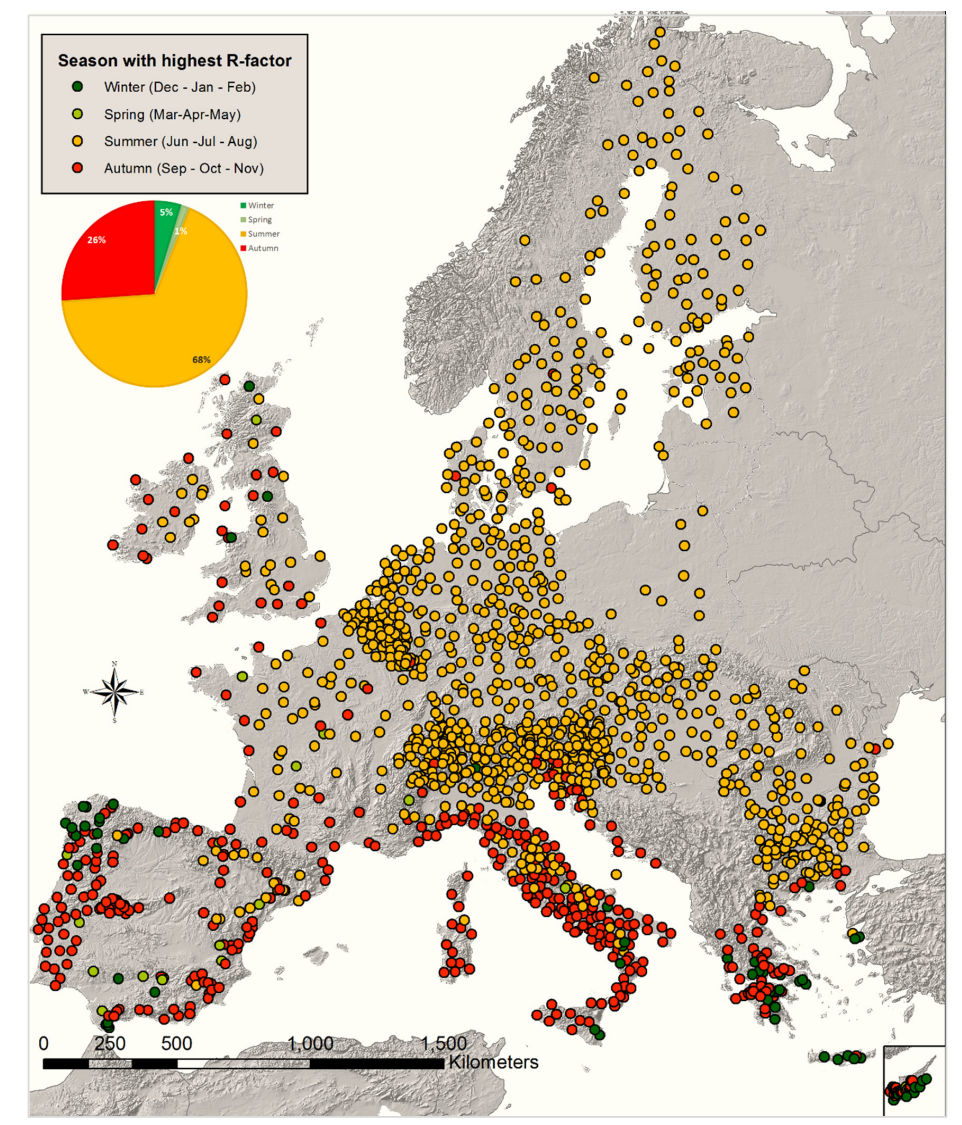

Figure 5. Spatial distribution of largest seasonal R-factor values in REDES. 
The R-factor shows the largest monthly values in autumn across most of the Mediterranean region, where the precipitation amount is generally larger in October-November [31,32] and summers are frequently hot and dry [33]. Southern Greece and Cyprus can be considered to be an exception in $\mathrm{R}$-factor patterns of the Mediterranean region, as the rainfall erosivity peaks in winter and it is small in spring even if those regions show a similar rainfall amount compared to autumn [34].

The Atlantic regions do not show distinctive patterns, probably because the monthly precipitation variability is smaller than in the continental regions [35], especially in the British Islands [36,37]. The R-factor is largest in summer in Central Europe, Northern Europe, Eastern Europe and the Alps. This pattern might have different explanations, as Central Europe is generally affected by large-scale extreme precipitation events in summer [38], while the Alps are usually affected by local summer thunderstorms and rain showers, due to the remarkable temperature gradients between hot and moist lowlands and cool and windy mountains $[11,39,40]$. Similar patterns can be found in the Carpathians and Eastern Europe [41-43]. Finally, Scandinavia shows higher variability in summer, but one should not forget that in winter, the precipitation events at high-latitudes are often in the form of snowfall and so we expect much fewer erosive events in winter compared to summer [44]. The stations with an almost zero R-factor during winter months are located in Central and Eastern European countries (Czech Republic, Slovakia, Bulgaria, and Romania) and in the Northern ones (Sweden and Finland).

Regarding the most erosive months for single stations, we found that in almost $30 \%$ of REDES, the most erosive month is July, followed by August (23.7\%) and June (12.7\%). On the contrary, the months with the least number of stations having the largest R-factor values are April and March. On average, the most erosive month of the year accounts for $28 \%$ of the total annual erosivity. In the Baltic and high-latitude regions, the most erosive month (either July or August) accounts for more than $38 \%$ of the annual R-factor. Lastly, the situation is much smoother in Ireland where the most erosive month is not a peak as it contributes only $16 \%$ to the total annual erosivity.

Besides the most erosive season or the most erosive month (in terms of R-factor), it is worth identifying the different intra-annual patters of the R-factor in the European continent. Most of the countries have been grouped based on their geographical position and their monthly patterns of rainfall erosivity (Figure 6). The distribution of the monthly erosivity in the Mediterranean countries (Spain, Portugal, Greece and Cyprus) (Figure 6a) follows a bathtub shaped curve [45], as three periods can be identified. Rainfall erosivity is more or less stable in the period from February to June and then shows a decrease in July and August (second period). Finally, December is the most erosive in Greece and Cyprus, while October has the largest values in the Iberian Peninsula (Figure 6a).

The temporal distribution of rainfall erosivity is very similar in Switzerland and Austria (Figure 6b), having the largest values in July and August. Instead, Northern Italy and Croatia show their peak values in September. These countries have the largest mean monthly values in REDES.

In Germany, The Netherlands, Belgium and Denmark, the rainfall erosivity is very limited during winter and early spring, then increases in May-June-July (and August in Denmark), followed by a sharp decrease in autumn (Figure 6c). The monthly R-factor distribution follows a Gaussian shape [46] in Germany, The Netherlands, Belgium and Denmark. Contrary to the three above-mentioned regional patterns (Mediterranean, Alpine, North Europe), Ireland, United Kingdom and France show the smoothest distribution during the whole year (Figure 6d).

The remaining countries (Scandinavia, Baltic States, and Central Europe) follow the distribution identified in North Europe (The Netherlands, Germany, Denmark), as shown in Figure 6c. Using the Cubist spatial interpolation model [47], we have developed the first predictions of monthly erosivity maps. The R-factor maps of January and July (Figure 7) usually represent opposite winter and summer peak values. This is a first important application of the monthly REDES regarding the monthly conversion factors and the derived monthly rainfall erosivity maps. 

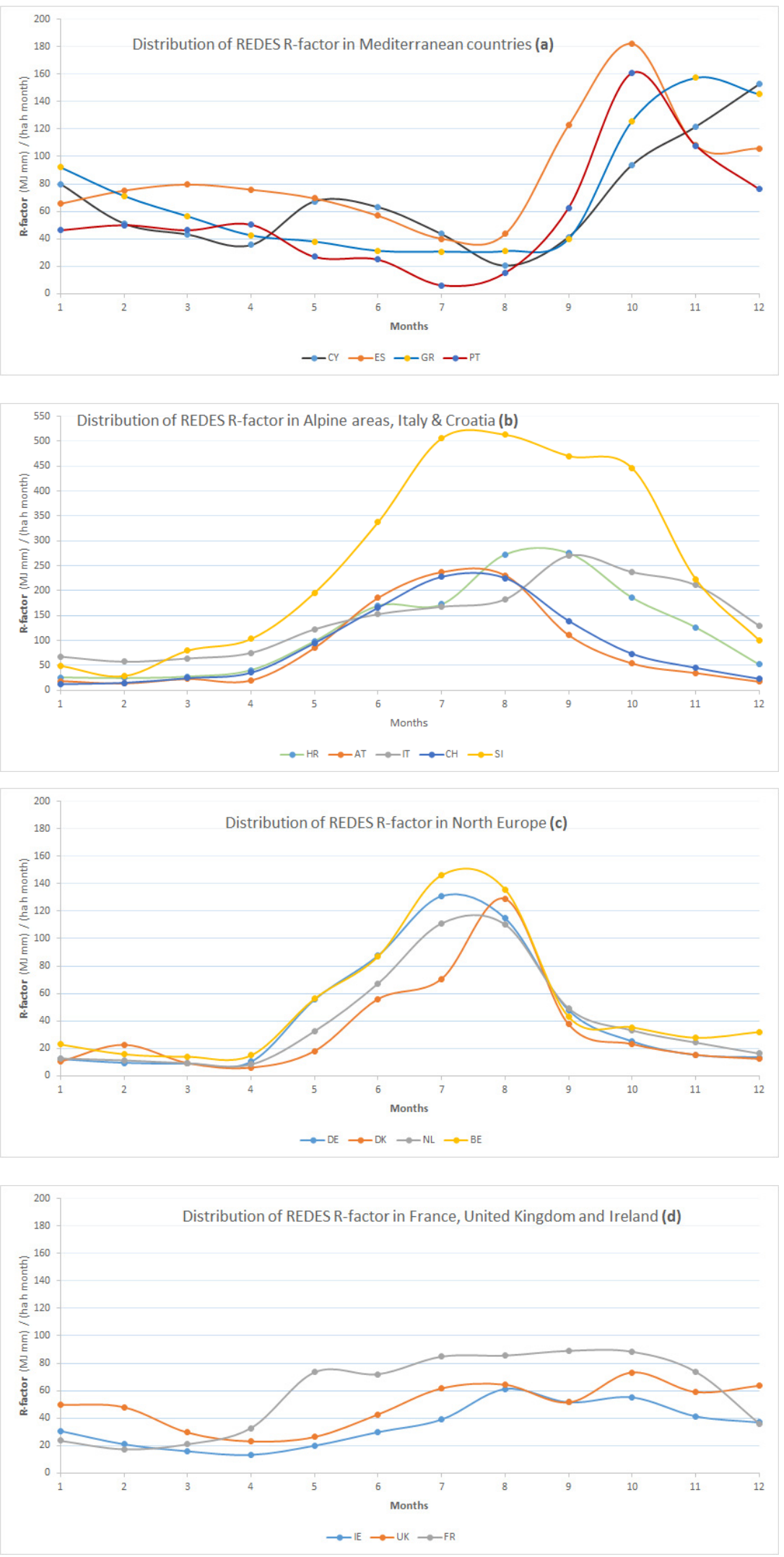

Figure 6. The main regional patterns of monthly rainfall erosivity in Europe: (a) Mediterranean countries (CY-Cyprus, GR-Greece, ES-Spain, PT-Portugal); (b) Alpine areas, Italy and Croatia (IT-Italy, CH-Switzerland, HR-Croatia, AT-Austria, SI-Slovenia); (c) North Europe (DE-Germany, DK—Denmark, NL-The Netherlands, BE-Belgium); (d) IE-Ireland, UK-United Kingdom, FR-France. 


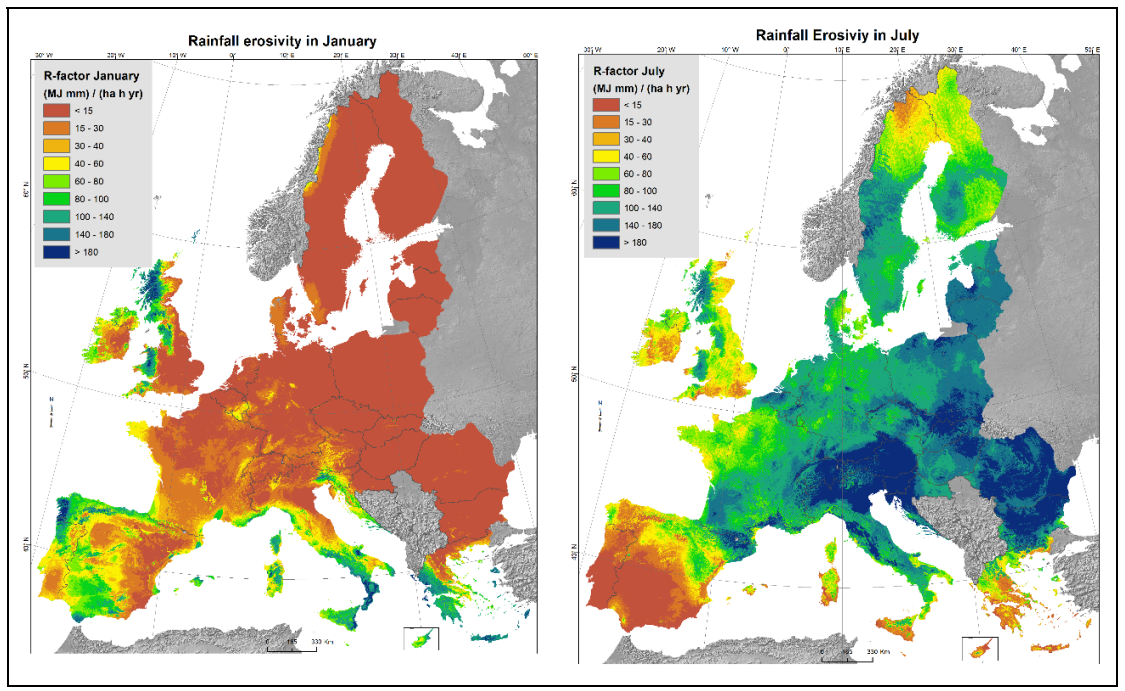

Figure 7. Monthly erosivity maps for Europe (Left: January; Right: July).

The magnitude of predicted climate change is likely to have a different influence on soil erosion depending on regional conditions [48,49]. As the predictions in climate change scenarios are expected to increase the number of storms during the summer months $[18,50]$, the countries with large erosivity during summer are projected to be more affected. However, the projected rainfall erosivity changes in Europe based on Intergovernmental Panel on Climate Change (IPCC) climatic change scenarios and REDES are planned in the near future.

\subsection{Monthly Rainfall Erosivity Density}

Similar to annual erosivity density [7,51,52], the Monthly Erosivity Density (MED) expresses the rainfall erosivity per rainfall unit $(\mathrm{mm})$ for each month. The erosivity density is highly reliant on rainfall intensity and, on event basis, influences event sediment concentration (soil loss per unit quantity of water). Dabney et al. [53] used the monthly erosivity density to demonstrate the impact of climate change in increasing runoff and soil loss. For each station in REDES, the Monthly Erosivity Density $(M E D i)$ for the $i$-th month is defined as the ratio of mean rainfall erosivity $(\mathrm{R})$ for the $i$-th month divided by its mean precipitation $(\mathrm{P})$ :

$$
M E D_{i}=R_{i} / P_{i}
$$

Large $M E D$ values suggest that rainfall occurs in the form of high intensity events (rainstorms) during the respective month. The distribution of MEDs in Europe is left skewed. Half of the monthly REDES records have an erosivity density smaller than 0.45 , while the 75 th percentile is close to 1 .

Some countries have similar characteristics regarding their MED and the corresponding monthly variability. For example, for all months, the mean MED in Sweden, Finland, Denmark, Germany, Netherlands, France, Ireland and United Kingdom is less than 1.62 (Figure 8). In these countries, MED is always smaller than 0.40 in winter-early spring (December, January, February, March, April). For these eight countries, the largest MED can be found either in July or August varying from 0.57 (Ireland) to 1.62 (France).

The Northern European countries show similar monthly variability regarding erosivity density (Figure 8a). The Gaussian distribution of mean monthly erosivity density is represented with the "bell-shaped curve", increasing during May to June, reaching its largest in July and then having a sharp decrease during early autumn. In France, the larger values of MED are due to larger R-factor values in the Alpine areas. 

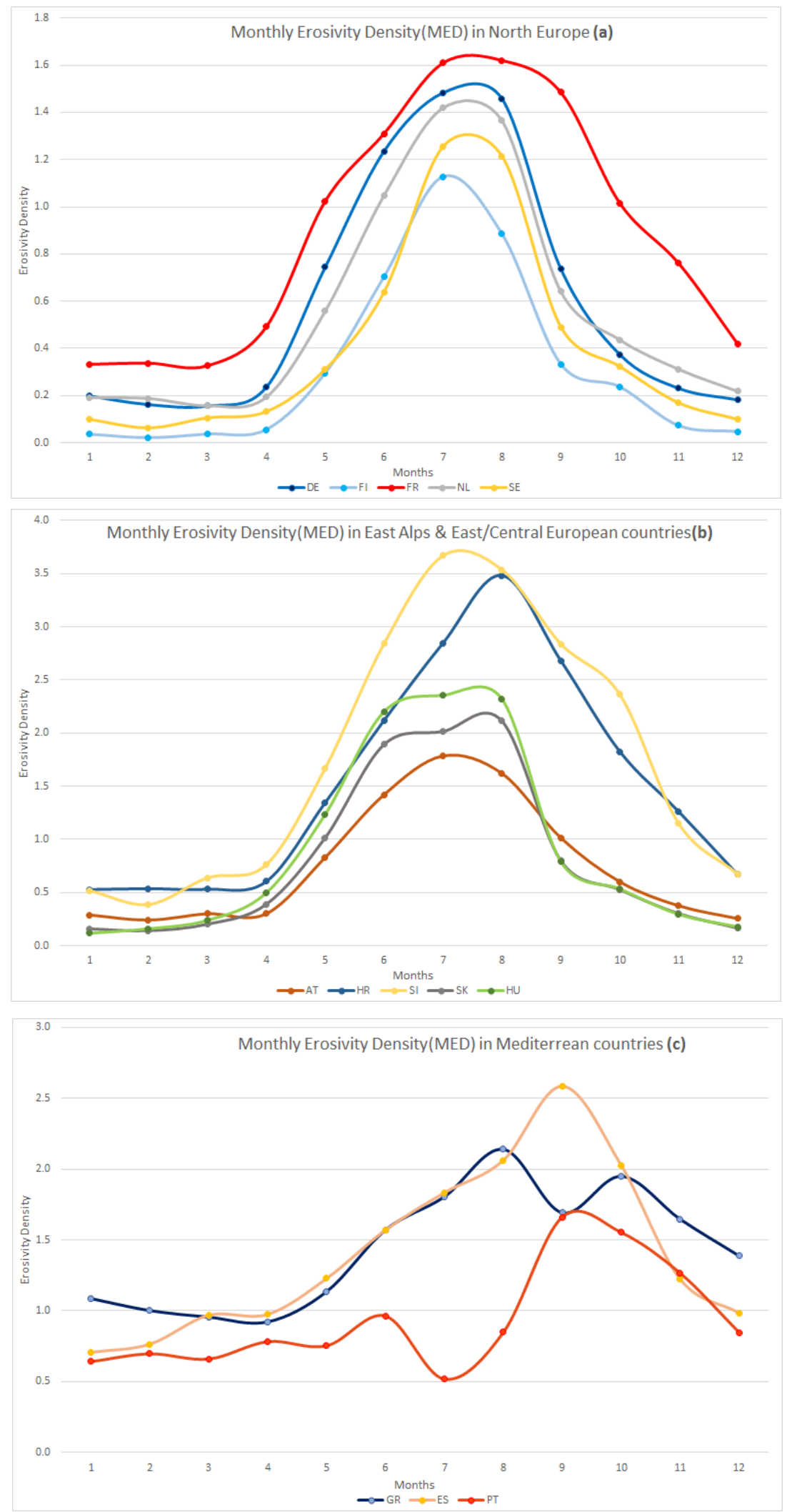

Figure 8. The main regional patterns of monthly erosivity density (MED): (a) North Europe (DE-Germany, FI-Finland, FR-France, NL-The Netherlands, SE-Sweden); (b) East Alps and East/Central European Countries (AT-Austria, HR-Croatia, SI-Slovenia, SK-Slovakia, HU—Hungary); (c) Mediterrean countries (GR-Greece, ES—Spain, PT—Portugal). 
The mean MED reaches the largest values (close to 3.67 during summer) in the Eastern Alps (Slovenia, North-East Italy) and Croatia; in Central European countries (Austria, Slovakia, and Hungary), the mean MED is larger than 1.65 during summer (Figure 8b). In all of these countries, the winter and early spring are characterized by a relatively small MED $(<0.75)$.

In Ireland and the United Kingdom, MEDs are very smooth compared with the rest of European countries and have values ranging between 0.19 (April) to 0.78 (July). The Mediterranean countries are quite different from the rest of the European countries, as their largest MED is found in September or August (Figure 8c). Moreover, the winter months in Spain and Greece have MEDs close to 1, which is not noted in Northern Europe.

\section{Conclusions}

In this study, calibration factors for transferring the R-factor values between different time resolutions on a monthly scale have been produced; these can be applied in case of monthly or annual estimation of R-factors in any part of Europe. As expected, the calculated rainfall erosivity values decrease as the rainfall measurement interval increases. According to our analyses, the relationship between time resolution and conversion factors is exponential, different from past assessments that proposed linear functions $[4,16]$. The coefficients of different resolutions for monthly rainfall erosivity allow normalizing the monthly R-factor values to a common 30-min resolution for all the REDES stations. The development of the monthly dimension in the REDES database allows the assessment and modeling of the R-factor at the monthly and seasonal levels.

Compared to the study of Diodato and Bellocchi [54], who investigated the decadal rainfall-runoff erosivity in Central Europe and the Mediterranean region, this study is based on a larger input dataset, introduces a different methodology, analyzes the rainfall erosivity spatial patterns on a monthly basis and covers a much wider area (European Union plus Switzerland). One of the most relevant findings is the assessment of the regions that can be considered under threat from rainfall erosivity: the Alpine region is characterized by high erosivity during summer and early autumn (July to September), while the Mediterranean region has its largest peaks in late autumn and early winter. Consideration of monthly rainfall erosivity patterns is crucial for landscape and catchments management for an optimization of agricultural land use (vegetation cover, support practices) and natural hazard prediction (soil erosion, landslides and floods).

For instance, it is important to maintain vegetation coverage in Central and Northern European countries during summer months while October to December is the most critical season for Mediterranean countries. Identifying the most erosive season (month) per country (region) can contribute to mitigate soil erosion by protecting soil with vegetation coverage and applying appropriate management practices. As topography and soil properties are soil erosion drivers that are more constant over time, the vegetation coverage and crop management are the factors that can be primarily influenced by human intervention.

Finally, the new proposed monthly erosivity density index identifies the most risky seasons in terms of floods and erosive events, as large monthly erosivity density values correspond to seasons and areas with high intensity of rainfall creating extreme erosive events. Based on this index, the erosive events in summer months in the Eastern Alps and Central Europe and in autumn in the Mediterranean area may lead to R-factor values that range from two to four times the corresponding rainfall amounts.

Acknowledgments: The authors would like to acknowledge the following services for providing access to their data:

Austria: Hydrographic offices of Upper Austria, Lower Austria, Burgenland, Styria, Salzburg, Carinthia, Vorarlberg and Tyrol.

Belgium-Flanders: Flemish Environmental Agency (VMM), Operational Water Management.

Belgium-Wallonia: Service public de Wallonie, Direction générale Mobilité et Voies hydrauliques, Direction de la Gestion hydrologique intégrée, Namur.

Bulgaria: Rousseva et al. (2010).

Cyprus: Cyprus Department of Meteorology.

Czech Republic: Research Institute for Soil and Water Conservation, Prague, Czech Republic. 
Germany: Deutscher Wetterdienst (DWD), WebWerdis Service.

Denmark: Aarhus University, Department of Agroecology.

Estonia: Client service department, Estonian Environment Agency, Tallinn.

Spain: Confederaciones Hidrográficas del Ebro, Tajo, Duero, Guadalquivir, Segura, Júcar, Miño-Sil, Cantábrico and Sur, Servei Meteorològic de Catalunya, and Meteo Navarra.

France: Météo-France DP/SERV /FDP, Division Fourniture de Données Publiques.

Greece: Hydroskopio.

Croatia: Meteorological and Hydrological Service.

Hungary: Hungarian Meteorological Service.

Ireland: Data from Met Éireann, financial support from Irish EPA STRIVE Programme-SILTFLUX (2010-W-LS-4) and UCD Earth Institute.

Italy: the Servizio Idrografico Abruzzo, Protezione Civile Regione Basilicata, Ufficio idrografico Bolzano, Servizio Idrografico Friuli-Venezia Giulia, Centro funzionale regione Lazio, Meteotrentino, Agenzia Regionale per lo Sviluppo e l'Innovazione dell'Agricoltura nel Molise, Servizio Meteo-Idro-Pluviometrico Marche, Associazione Regionale dei Consorzi di Difesa della Puglia, Osservatorio delle Acque Sicilia, Servizio Idrologico Regionale Toscana, Servizio Risorse idriche e rischio idraulico Umbria, Diodato Nazzareno from Regione Campagna, Centro funzionale regionale Valle d'Aosta and the Hydro-Meteo-Climate Service of the Environmental Agency ARPA Calabria, ARPA Emilia Romagna, ARPA Liguria, ARPA Lombardia, ARPA Piemonte, ARPA Veneto.

Latvia: Latvian Environment, Geology and Meteorology Centre, Riga.

Luxembourg: Agrarmeteorologisches Messnetz Luxembourg.

Netherlands: KNMI, Royal Netherlands Meteorological Institute

Portugal: Agência Portuguesa do Ambiente, Departamento de Monitorização de Recursos Hídricos.

Poland: Warsaw University of Life Sciences.

Romania: Meteo Romania (National Meteorological Administration.

Slovakia: Slovak Hydrometeorological Institute, Climatological service.

Slovenia: Slovenian Environment Agency, Meteorology Office.

Sweden: Swedish Meteorological and Hydrological Institute (SMHI).

United Kingdom: NERC \& UK Environmental Change Network (ECN), and British Atmospheric Data Centre (BADC).

Author Contributions: P. Panagos, P. Borelli, S. Beguería, A. Klik, S. Michaelides, S. Petan, M. Hrabalíková, P. Olsen, J. Aalto, M. Lakatos, A. Rymszewicz, A. Dumitrescu, M. Perčec Tadić, N. Diodato, J. Kostalova, S. Rousseva, K. Banasik analyzed the data; P. Panagos, P. Borrelli, K. Meusburger, C. Alewell, J. Spinoni and C. Ballabio wrote the paper.

Conflicts of Interest: The authors declare no conflict of interest.

\section{References}

1. Lal, R. Soil degradation by erosion. Land Degrad. Dev. 2001, 12, 519-539. [CrossRef]

2. Panagos, P.; Meusburger, K.; Van Liedekerke, M.; Alewell, C.; Hiederer, R.; Montanarella, L. Assessing soil erosion in Europe based on data collected through a European Network. Soil Sci. Plant Nutr. 2014, 60, 15-29. [CrossRef]

3. Wang, G.; Gertner, G.; Singh, V.; Shinkareva, S.; Parysow, P.; Anderson, A. Spatial and temporal prediction and uncertainty of soil loss using the revised universal soil loss equation: A case study of the rainfall-runoff erosivity R factor. Ecol. Model. 2002, 153, 143-155. [CrossRef]

4. Renard, K.G.; Foster, G.A.; Weesies, G.A.; McCool, D.K.; Yoder, D.C. Predicting Soil Erosion by Water: A Guide to Conservation Planning with the Revised Universal Soil Loss Equation (RUSLE); Agricultural Handbook 703. US Department of Agriculture: Washington, DC, USA, 1997; pp. 1-404.

5. Wischmeier, W.; Smith, D. Predicting Rainfall Erosion Losses: A Guide to Conservation Planning; Agricultural Handbook No. 537. U.S. Department of Agriculture: Washington, DC, USA, 1978.

6. Istok, J.D.; McCool, D.K.; King, L.G.; Boersma, L. Effect of rainfall measurement interval on EI calculation. Trans. Am. Soc. Agric. Eng. 1986, 29, 730-734. [CrossRef]

7. Panagos, P.; Ballabio, C.; Borrelli, P.; Meusburger, K.; Klik, A.; Rousseva, S.; Tadic, M.P.; Michaelides, S.; Hrabalíková, M.; Olsen, P.; et al. Rainfall erosivity in Europe. Sci. Total Environ. 2015, 511, 801-814. [CrossRef] [PubMed]

8. Brown, L.C.; Foster, G.R. Storm erosivity using idealized intensity distributions. Trans. ASAE 1987, 30, 379-386. [CrossRef]

9. Panagos, P.; Meusburger, K.; Ballabio, C.; Borrelli, P.; Begueria, S.; Klik, A.; Rymszewicz, A.; Michaelides, S.; Olsen, P.; Tadic, M.P.; et al. Reply to the comment on "Rainfall erosivity in Europe" by Auerswald et al.. Sci.Total Environ. 2015, 532, 853-857. [CrossRef] [PubMed] 
10. Diodato, N. Predicting RUSLE (Revised Universal Soil Loss Equation) monthly erosivity index from readily available rainfall data in Mediterranean area. Environmentalist 2006, 26, 63-70. [CrossRef]

11. Meusburger, K.; Steel, A.; Panagos, P.; Montanarella, L.; Alewell, C. Spatial and temporal variability of rainfall erosivity factor for Switzerland. Hydrol. Earth Syst. Sci. 2012, 16, 167-177. [CrossRef]

12. Sadeghi, S.H.R.; Hazbavi, Z. Trend analysis of the rainfall erosivity index at different time scales in Iran. Nat. Hazard. 2015, 77, 383-404. [CrossRef]

13. Panagos, P.; Ballabio, C.; Borrelli, P.; Meusburger, K. Spatio-temporal analysis of rainfall erosivity and erosivity density in Greece. Catena 2016, 137, 161-172. [CrossRef]

14. Klik, A.; Konecny, F. Rainfall erosivity in northeastern Austria. Trans. ASABE 2013, 56, 719-725. [CrossRef]

15. Weiss, L.L. Ratio of true to fixed-interval maximum rainfall. J. Hydraul. Div. 1964, 90, 77-82.

16. Yin, S.; Xie, Y.; Nearing, M.A.; Wang, C. Estimation of rainfall erosivity using 5- to 60-minute fixed-interval rainfall data from China. CATENA 2007, 70, 306-312. [CrossRef]

17. Agnese, C.; Bagarello, V.; Corrao, C.; D'Agostino, L.; D'Asaro, F. Influence of the rainfall measurement interval on the erosivity determinations in the Mediterranean area. J. Hydrol. 2006, 329, 39-48. [CrossRef]

18. Coumou, D.; Rahmstorf, S. A decade of weather extremes. Nat. Clim. Chang. 2012, 2, 491-496. [CrossRef]

19. Pachauri, R.K.; Allen, M.R.; Barros, V.R.; Broome, J.; Cramer, W.; Christ, R.; van Vuuren, D. Climate Change 2014: Synthesis Report; Contribution of Working Groups I, II and III to the Fifth Assessment Report of the Intergovernmental Panel on Climate Change; Alfred-Wegener-Institut (AWI): Potsdam, Germany, 2014.

20. Porto, P. Exploring the effect of different time resolutions to calculate the rainfall erosivity factor R in Calabria, southern Italy. Hydrol. Process. 2015. in press. [CrossRef]

21. Williams, R.G.; Sheridan, J.M. Effect of measurement time and depth resolution on EI calculation. Trans. ASAE 1991, 34, 402-405. [CrossRef]

22. Wang, Y.; Zhou, L. Observed trends in extreme precipitation events in China during 1961-2001 and the associated changes in large-scale circulation. Geophys. Rese. Lett. 2005, 32. [CrossRef]

23. Zhai, P.M.; Pan, X.H. Change in extreme temperature and precipitation over northern China during the second half of the 20th century. Acta Geogr. Sin. 2003, 58, 1-10.

24. Pauling, A.; Luterbacher, J.; Casty, C.; Wanner, H. Five hundred years of gridded high-resolution precipitation reconstructions over Europe and the connection to large-scale circulation. Clim. Dyn. 2006, 26, 387-405. [CrossRef]

25. Wei, W.; Chen, L.; Fu, B.; Huang, Z.; Wu, D.; Gui, L. The effect of land uses and rainfall regimes on runoff and soil erosion in the semi-arid loess hilly area, China. J. hydrol. 2007, 335, 247-258. [CrossRef]

26. Gudmundsson, L.; Wagener, T.; Tallaksen, L.M.; Engeland, K. Evaluation of nine large-scale hydrological models with respect to the seasonal runoff climatology in Europe. Water Resour. Res. 2012, 48. [CrossRef]

27. Marker, M.; Angeli, L.; Bottai, L.; Costantini, R.; Ferrari, R.; Innocenti, L.; Siciliano, G. Assessment of land degradation susceptibility by scenario analysis: A case study in Southern Tuscany, Italy. Geomorphology 2008, 93, 120-129. [CrossRef]

28. Panagos, P.; Borrelli, P.; Poesen, J.; Ballabio, C.; Lugato, E.; Meusburger, K.; Montanarella, L.; Alewell, C. The new assessment of soil loss by water erosion in Europe. Environ. Sci. Policy 2015, 54, 438-447. [CrossRef]

29. Hoyos, N.; Waylen, P.R.; Jaramillo, A. Seasonal and spatial patterns of erosivity in a tropical watershed of the Colombian Andes. J. Hydrol. 2005, 314, 177-191. [CrossRef]

30. Panagos, P.; Borrelli, P.; Meusburger, C.; Alewell, C.; Lugato, E.; Montanarella, L. Estimating the soil erosion cover-management factor at European scale. Land Use Policy 2015, 48, 38-50. [CrossRef]

31. Klein Tank, A.M.G.; Wijngaard, J.B.; Können, G.P.; Böhm, R.; Demarée, G.; Gocheva, A.; Mileta, M.; Pashiardis, S.; Hejkrlik, L.; Kern-Hansen, C.; et al. Daily dataset of 20th-century surface air temperature and precipitation series for the European Climate Assessment. Int. J. Climatol. 2002, 22, 1441-1453. [CrossRef]

32. González-Hidalgo, J.C.; Brunetti, M.; de Luis, M. A new tool for monthly precipitation analysis in Spain: MOPREDAS database (monthly precipitation trends December 1945-November 2005). Int. J. Climatol. 2011, 31, 715-731. [CrossRef]

33. Hoerling, M.; Eischeid, J.; Perlwitz, J.; Quan, X.; Zhang, T.; Pegion, P. On the increased frequency of Mediterranean drought. J. Clim. 2012, 25, 2146-2161. [CrossRef]

34. Xoplaki, E.; Gonzalez-Rouco, J.F.; Luterbacher, J.U.; Wanner, H. Wet season Mediterranean precipitation variability: influence of large-scale dynamics and trends. Clim. Dyn. 2004, 23, 63-78. [CrossRef] 
35. Wibig, J. Precipitation in Europe in relation to circulation patterns at the $500 \mathrm{hPa}$ level. Int. J. Climatol. 1999, 19, 253-269. [CrossRef]

36. Lloyd-Hughes, B.; Saunders, M.A. Seasonal prediction of European spring precipitation from El Niño-Southern Oscillation and Local sea-surface temperatures. Int. J. Climatol. 2002, 22, 1-14. [CrossRef]

37. Haylock, M.R.; Hofstra, N.; Klein Tank, A.M.G.; Klok, E.J.; Jones, P.D.; New, M. A European daily high-resolution gridded data set of surface temperature and precipitation for 1950-2006. J. Geophys. Res. Atmos. 2008, 113. [CrossRef]

38. Frei, C.; Davies, H.C.; Gurtz, J.; Schär, C. Climate dynamics and extreme precipitation and flood events in Central Europe. Integr. Assess. 2000, 1, 281-300. [CrossRef]

39. Peristeri, M.; Ulrich, W.; Smith, R.K. Genesis conditions for thunderstorm growth and the development of a squall line in the northern alpine foreland. Meteorol. Atmos. Phys. 2000, 72, 251-260. [CrossRef]

40. Christian, H.J.; Blakeslee, R.J.; Boccippio, D.J.; Boeck, W.L.; Buechler, D.E.; Driscoll, K.T.; Goodman, S.J.; Hall, J.M.; Koshak, W.J.; March, D.M.; et al. Global frequency and distribution of lightning as observed from space by the Optical Transient Detector. J. Geophys. Res. Atmospheres 2003, 108. [CrossRef]

41. Bartholy, J.; Pongrácz, R. Regional analysis of extreme temperature and precipitation indices for the Carpathian Basin from 1946 to 2001. Glob. Planet. Chang. 2007, 57, 83-95. [CrossRef]

42. Spinoni, J.; Szalai, S.; Szentimrey, T.; Lakatos, M.; Bihari, Z.; Nagy, A.; Nemeth, A.; Kovacs, T.; Mihic, D.; Dacic, M.; et al. Climate of the Carpathian Region in the period 1961-2010: climatologies and trends of 10 variables. Int. J. Climatol. 2015, 35, 1322-1341. [CrossRef]

43. Dumitrescu, A.; Birsan, M.V.; Manea, A. Spatio-temporal interpolation of sub-daily (6 h) precipitation over Romania for the period 1975-2010. Int. J. Climatol. 2015, 36, 1331-1343. [CrossRef]

44. Linderson, M.L. Objective classification of atmospheric circulation over southern Scandinavia. Int. J. Climatol. 2001, 21, 155-169. [CrossRef]

45. Klutke, G.A.; Kiessler, P.C.; Wortman, M.A. A critical look at the bathtub curve. IEEE Trans. Reliab. 2003, 52, 125-129. [CrossRef]

46. Sharma, A. Seasonal to interannual rainfall probabilistic forecasts for improved water supply management: Part 3-A nonparametric probabilistic forecast model. J. Hydrol. 2000, 239, 249-258. [CrossRef]

47. Quinlan, J.R. Combining instance-based and model based learning. In Proceedings of the Tenth International Conference on Machine Learning, Amherst, MA, USA, 27-29 June 1993; Morgan Kaufman: Burlington, MA, USA, 2013; pp. 236-243.

48. Blanco, H.; Lal, R. Principles of Soil Conservation and Management; Springer Science \& Business Media: Berlin, Heidelberg, Germany, 2008; pp. 513-534.

49. O'Neal, M.R.; Nearing, M.A.; Vining, R.C.; Southworth, J.; Pfeifer, R.A. Climate change impacts on soil erosion in Midwest United States with changes in crop management. Catena 2005, 61, 165-184. [CrossRef]

50. Orlowsky, B.; Seneviratne, S.I. Global changes in extreme events: Regional and seasonal dimension. Clim. Chang. 2012, 110, 669-696. [CrossRef]

51. Kinnell, P.I.A. Event soil loss, runoff and the Universal Soil Loss Equation family of models: A review. J. Hydrol. 2010, 385, 384-397. [CrossRef]

52. Bonilla, C.A.; Vidal, K.L. Rainfall erosivity in Central Chile. J. Hydrol. 2011, 410, 126-133. [CrossRef]

53. Dabney, S.M.; Yoder, D.C.; Vieira, D.A.N. The application of the Revised Universal Soil Loss Equation, Version 2, to evaluate the impacts of alternative climate change scenarios on runoff and sediment yield. J. Soil Water Conserv. 2012, 67, 343-353. [CrossRef]

54. Diodato, N.; Bellocchi, G. Decadal modelling of rainfall-runoff erosivity in the Euro-Mediterranean region using extreme precipitation indices. Glob. Planet. Chang. 2012, 86, 79-91. [CrossRef]

(c) 2016 by the authors; licensee MDPI, Basel, Switzerland. This article is an open access article distributed under the terms and conditions of the Creative Commons by Attribution (CC-BY) license (http://creativecommons.org/licenses/by/4.0/). 